\title{
Sinematek Indonesia: Formidable Achievements in Film Collection and Research - But a Collection Under Threat David Hanan
}

Sinematek Indonesia, the archive for feature films in Indonesia, was the first film archive established in South East Asia. The article outlines the circumstances of its establishment in 1975, as a result of negotiations between a progressive governor of Jakarta and filmmakers and educators, but shows how this, and subsequent funding frameworks outside of central government funding, has led to its current situation. The history of the Sinematek is discussed in the context of changing eras of Indonesian history. While highlighting the achievements of Sinematek Indonesia in film collection and research, it emphasizes that its remarkable collection of films on celluoid is under threat because there is no regular budget for film restoration or even for proper preservation. Also outlined is recent cooperation between Sinematek and the newly established 'Indonesian Film Center' in the digitization of its collection. The article is as much a memoir, as an academic article, for much of the information here is based on Hanan's regular engagement with the archive since 1981, which has included providing subtitles for film classics in its collection, and organizing occasional film preservation projects for educational purposes.

Keywords: Indonesia, film preservation, film restoration, archives, digitization

Sinematek Indonesia, the film archive holding the most substantial collection of feature films made in Indonesia, opened in 1975. It was the first film archive established in South East Asia. Sinematek Indonesia is a rich case study because it shows the problems that may be encountered by a film archive set up in a developing society, only some 25 years after the end of more than 130 years of intensive colonization. Despite its role in preserving a large number of unique Indonesian films, Sinematek Indonesia rarely received national government funding for its preservation or restoration projects during its first forty years of existence, unlike film archives established in socialist or communist societies in the post-independence period, such as in Vietnam, whose film archive was established in 1979. One particularly admirable feature of Sinematek Indonesia is that its founding staff, H. Misbach Biran and S.M. Ardan, saw their function not simply as one of administrators collecting and preserving films, but of authors documenting and writing about the history of film in Indonesia, and even about the history of the archive itself (Biran, 2008, pp. 221-73). ${ }^{1}$ 
Although films were first shown in Indonesia as early as 1896, and "early actualities" were filmed in Indonesia by the Dutch within the next few years, it was not until 1926 that a feature film was produced. Arguably, the first feature film made in the country, known at that time as the Netherlands East Indies, was Loetoeng Kasoerung [The Enchanted Monkey] (1926), based on a West Javanese legend and directed by the Dutchman L. Heuveldorp for his company Java Film (Biran, 2009, pp. 60-71). Funding for this film was provided by the Regent of Bandung, Raden Wiranatakusuma, who some years earlier had sponsored a staged version of the same story. The main pioneers of the film industry in Indonesia over the next 25 years were local and immigrant Chinese, this being due partly to the importance of the Chinese in the modernizing economy and the fact that those Chinese playing leading roles, such as the Wong Brothers and The Teng Chun, had some overseas experience in film, whether in Shanghai or the United States (Biran, 2009, pp. 77-113; 135-41; 147-55; 208-312; Hanan, 2017, pp. 53-65). During this 25-year period, about 114 films were made. The sudden expansion in the film industry that occurred in the late 1930s was interrupted by the invasion of the Japanese in 1942, when World War II broke out in South East Asia.

With the coming of independence from the Dutch at the end of 1949 came the emergence of some key indigenous filmmakers, most notably within the Perfini Company established in 1950 by writer-producer-director Usmar Ismail and his associates. The film industry in Indonesia has been particularly strong in the 1950s, 1970s, and 1980s and since about the year 2000, with steep declines in production in the 1960s and 1990s (Hanan, 2017, pp. 53-90). Sinematek Indonesia contains a significant collection of films from all of these post-independent decades. The number of films from the colonial period, though, is small, for reasons that will be explained later.

Under Indonesian government legislation dating back to 1980, the government-funded Arsip Nasional (National Archive), located in South Jakarta, has the main responsibility for archival preservation of important national documents, including government documentary films produced from 1950 onwards by Perusahaan Film Negara (PFN), the State Film Company, also known at times as Pusat Produksi Film Negara, State Film Production Center (PPFN) (National Archives of the Republic of Indonesia, 2014, p. 20; Minarchek, 2015). But the Arsip Nasional preservation responsibilities do not extend to commercially-funded feature films. The Arsip Nasional collection is mostly documentary and newsreel. The Sinematek collection, which is non-state owned, i.e., private, is primarily known for its feature film collection. 
The lack of secure funding, especially for the restoration of films, led the founding Head of Sinematek Indonesia, H. Misbach Yusa Biran, to complain, only a year or so before his death in 2012, that Sinematek Indonesia was "like a man in a coma: it is still able to breathe but its body parts do not function" (Biran, 2011, p. 5). Fortunately, in the last three years or so, some good things have been happening around Sinematek Indonesia, in particular the establishment of the new Indonesian Film Centre in the same building. This center is in the process of digitizing the Sinematek collection.

This study of Sinematek Indonesia will cover a number of issues: the circumstances around its establishment in the 1970s and its growing collection of films; its changing funding framework over a 40 -year period; research output by its staff; limitations on preservation and how some limited preservation and restoration projects have been funded; the content and the scale of the collection, including questions about any partiality in the collection based on political considerations; and the facilities it offers to researchers. The article concludes with an outline of unresolved issues that Sinematek Indonesia is currently facing.

\section{Pre-History}

An account of the establishment of Sinematek Indonesia in the 1970s is important because it explains why it is in its current difficult situation. Such an account also highlights the many initiatives in the arts that occurred in the 1970s and helps explain why in many ways Jakarta, with regard to the arts, is a very vibrant city.

The founding of Sinematek Indonesia was really the work of two men who crossed paths and whose aims and interests coalesced in 1974. Between the two, the better known is Ali Sadikin (1927-2008), a former naval officer appointed as governor of Jakarta in 1966 by President Sukarno, with General Suharto's approval, and holding office until 1977. The dynamic Sadikin was a popular figure, remembered even today for his numerous diverse, if at times controversial, initiatives in modernizing the city. The second key figure is the founding Head of Sinematek Indonesia, H. Misbach Yusa Biran (19332012), well known in the Indonesian film world. Biran entered the film industry in Indonesia in 1955 and by the mid-1960s had become a director as well as a scriptwriter. Although Biran had made films that introduced new acting talent into the film industry, notably the actress Nani Widjaya, who later became his wife, and the comedian Benyamin S, he has claimed that as a devout Muslim he became increasingly dissatisfied with the highly commercial and exploitative direction he considered the film industry was taking in the early 1970s. He also decried the lack of professional training of the new people entering the rapidly expanding industry at a time when 
cinemascope and color were being introduced. At this point Biran's life took a new turn. He gave up working as a film director and became involved in film education and related cultural activities emerging in Jakarta at the time. This era is described comprehensively in Chapter X of Biran's autobiography (Biran, 2008, pp. 221-73).

In 1968, as newly-appointed Governor of Jakarta, Sadikin established the Dewan Kesenian Jakarta, the Jakarta Arts Council. This council was set up to oversee some important new developments in the arts that were to be funded by the city council. These included a cultural center near the center of the city, to be known as Taman Ismail Marzuki (The Garden of Ismail Marzuki), after the composer Marzuki. This cultural center would have facilities for live theater, dance and music performances, and film screenings; an art gallery; and, of course, traditional spaces for gamelan performances and related Indonesian traditional arts such as shadow puppetry. At the rear of this quite large open space, with numerous trees and food stalls, there was also to be a university of the arts, known initially as Lembaga Pendidikan Kesenian Jakarta (LPKJ) or the Institute for Arts Education in Jakarta, later known as Institut Kesenian Jakarta (IKJ) or the Jakarta Institute of the Arts. LPKJ included a faculty of cinematography. In the early 1970s, Sjuman Djaya, a recent Indonesian graduate of the AllUnion State Institute of Cinematography in Moscow (VGIK), was appointed as the founding Dean of this faculty. Over the next 15 years Sjuman Djaya himself would become one of Indonesia's most highly regarded filmmakers. Shortly after being appointed, Sjuman Djaya asked Biran to teach film history at LPKJ. At that time and even today, many of those teaching at IKJ are leading filmmakers, not simply scholars or full-time teachers. Today the faculty includes internationally acclaimed directors such as Garin Nugroho and Riri Riza.

When Biran began teaching at LPKJ, he particularly wished to include material on Indonesian film history in his curriculum, but he found there was little source material available on the topic apart from one short monograph published in 1953 by Armijn Pane (Pane, 1953). Accordingly, Biran himself began to research the history of Indonesian film, and this included locating and interviewing still-living early pioneers of the industry from the 1930s, many of whom were Chinese. In March 1972 Biran held an exhibition at Taman Ismail Marzuki that showcased the results of his research. To his surprise, his exhibition attracted a great deal of interest not only from the locals but also from cultural attachés of the embassies of France and Holland and ultimately from overseas scholars (Biran, 2008, 229-30, 239). Subsequently, Biran's research formed the basis of a dossier on the history of Indonesian cinema. This was published in a special edition of the French 
journal devoted to all matters Indonesian, Archipel, along with interviews with Indonesian filmmakers, and articles-one by Biran himself-on aspects of Indonesian and Malaysian cinema, mainly by French scholars, all of which were accompanied by photographs from Biran's collection (Ramadhan \& Biran, 1973; Lombard, 1973). At about the same time Biran was given a Netherlands government scholarship, that commenced in March 1973 , to be used specifically to make a study of the curatorial operations of the Netherlands Film Museum in Amsterdam for three months. While at the museum Biran photocopied its collection of newspaper articles about film in the Netherlands East Indies published locally in the colony from 1900 onwards. In this way he substantially augmented data he had already assembled in Jakarta, eventually to form the initial basis of the Sinematek library collection of clippings.

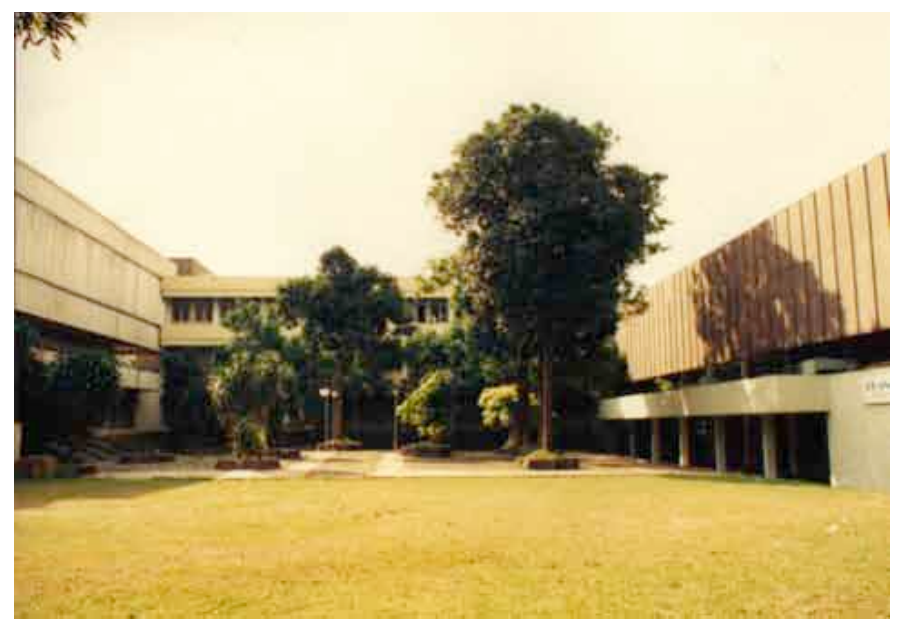

Fig. 1. Film Centre $\mathrm{H}$. Usmar Ismail at Kuningan in Central Jakarta, which opened in 1975 (Courtesy of Sinematek Indonesia).

In 1974 Governor Sadikin announced a new initiative. He wanted to create a film center given that the film industry in Jakarta was a major feature of the city. Biran reported in his autobiography that during only a brief meeting he held with Sadikin, he laid out a range of ideas that could form the basis for a film center: that it should not be simply a commercial center but a center of communication about film matters; that it should contain a film archive with storage facilities and offices for individual producers, film cooperatives that wanted to be based there, and industry unions, including the actors' union; and that it should have a large auditorium with projection facilities and a canteen (Biran, 2008, 244-47). A building was planned on vacant land in Jalan Rasuna Said, a boulevard in Kuningan in Central Jakarta. By the 1990s this road would become a major diplomatic and commercial area, referred to as the "Golden Triangle". The film center, known as Pusat 
Perfilman H. Usmar Ismail [Film Centre H. Usmar Ismail], was named after the man regarded by many as the key pioneer of an indigenous film industry, H. (Haji) Usmar Ismail, who had directed films from 1948 onwards, mainly for his own Perfini Company, and who died in 1971. The center included spaces for a film archive, and was inaugurated on 20 October 1975 (Biran, 2008, 249).

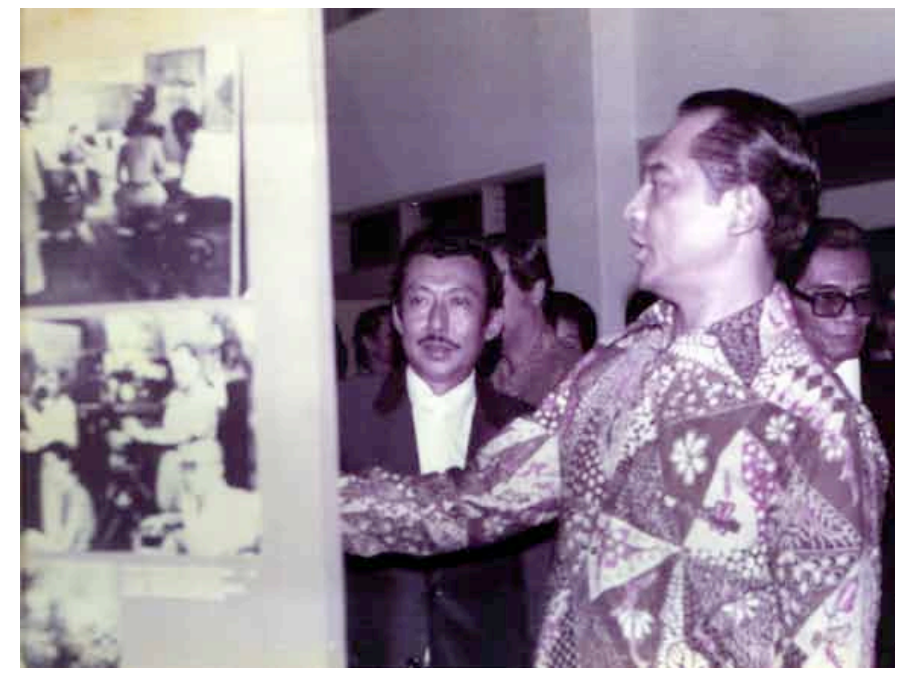

Fig. 2. Governor Ali Sadikin (right) at a Sinematek Indonesia Exhibition, accompanied by H. Misbach Biran (center) (Courtesy of Sinematek Indonesia).

\section{The First Twenty-five Years: Building the Collection on a Budget}

Misbach Biran remained Head of Sinematek Indonesia until 2000. It is highly probable that due to his strong industry connections, Biran was a particularly valuable person to have as founding head, for he, more than anyone else, could persuade companies to hand over to Sinematek their existing prints and negatives. Indeed, Biran did obtain a large number of prints and negatives of films made in the 1950s by the Perfini Company and other companies with whom he had associations. But, in fact, in the early years of the Sinematek many films were obtained not from production houses but from collectors, old village cinemas, and mobile cinema network groups known in Indonesia as bioskop keliling (Biran, 1998, p. 7). In the first decades of filmmaking in the Dutch East Indies, production houses did not have vaults, let alone air conditioning or cooling systems that might keep prints and negatives in good condition. Moreover, many pre-1960s companies had closed down and their negatives and prints discarded by the time Sinematek Indonesia was established in 1975. The early years of Sinematek Indonesia appear to have been good years. In 1977 Sinematek Indonesia became a member of the International Federation of Film Archives (FIAF), and it attracted international interest and attention (Biran, 2008, p. 251). 
Initially, operational funding for Sinematek Indonesia was provided by the Jakarta City Council, which had built the film center. But even though Sinematek was allowed to use the premises rent-free, operational funding, also provided by the council, lapsed in the late 1970s after the departure of Sadikin as governor of Jakarta. ${ }^{2}$ In 1980 a solution was found: funding was to come from the budget of the Indonesian Department of Information (the Ministry appointed by Sukarno in early 1964 to be responsible for film matters) via its subsidiary body, the Dewan Film Nasional [National Film Council], a consultative body of filmmakers and producers (Biran 2008, pp. 258-9). This funding was offered after Biran threatened to close Sinematek Indonesia. But it was only "subsistence funding", meaning it only covered the low salaries of the staff and very basic operating costs to prevent Sinematek Indonesia from closing down.

In 1978 Biran appointed the writer S. M. Ardan as deputy head of Sinematek, to be responsible for the establishment of the Sinematek library, which would come to include a huge collection of newspaper clippings, in addition to a growing collection of books, screenplays, and journals. Like Pak Misbach, Pak Ardan had written scripts for films, including the very successful Si Pitung (1970), which was about a local folk hero, and also collections of stories, and was himself an expert on Betawi or old Jakarta culture and its major theatrical form lenong Betawi (Ardan, Saputra, \& Sjafi'ie, 2000). Ardan was an assiduous administrator, very concerned about his poorly paid staff, and he developed an in-depth knowledge of Indonesian film history, its personnel, and its frameworks for distribution and exhibition.

In 1984, new regulations developed by the Dewan Film Nasional required a print of each film selected for competition in the annual Indonesian Film Festival (FFI) to be deposited with Sinematek, thus ensuring that prints of important recently produced films would be archived (Biran, personal communication, January 1985). Each print was to be provided by the film's producer, at no cost to Sinematek. However, these prints were often sent abroad to international film festivals, at the behest of the Dewan Film Nasional, so that they really had the status of viewing prints, not preservation prints. In this regard, it was not possible for Sinematek to follow archival best practice, which is to preserve, not screen, a print when there is neither a negative nor a preservation print in the archive.

In the mid-1990s, the collection of negatives at Sinematek was substantially augmented when the Dewan Film Nasional and the Indonesian Film Producers' Association jointly funded the return of color negatives that had been processed in Tokyo, Hong Kong, and Sydney since 1969 (Hartono, personal communication, December, 1998). These negatives, though not 
owned by Sinematek, are stored, and thus preserved, in the Sinematek vaults. A comparison of the lists of holdings that I recently undertook showed that of the 402 negatives returned from overseas, only about eleven of the titles were already held by Sinematek at the time. The majority of these newly acquired titles were not prize-winning Indonesian films to be shown in overseas festivals, but examples of popular cinema. However, not all the negatives processed overseas had survived. For example, 35-millimeter negatives of most films made by Sjuman Djaya's Matari Film Company were destroyed in Tokyo, presumably due to the company's inability to pay storage costs (Biran, personal communication, January 1981).

The destruction of negatives in the film industry in South East Asia is not uncommon. According to information supplied to me by staff at the National Museum of Singapore, in the late 1980s negatives and surviving prints of the films, made in the 1950s and 1960s by the remarkable singer, actor, writer, director, and megastar P. Ramlee for the Shaw Brothers Malay Films Productions Studio in Singapore, were destroyed, including the negatives and prints for his great comedies, presumably to save on cost of storage. Apparently the Shaw Studio executives believed that the future value of these films, made in black and white, lay only in television screenings or release on video or VCD, and decided to preserve them for future use only on Betacam tape, at best.

Despite its low level of funding, Sinematek Indonesia has played an exemplary role in Indonesia. In fact, it was only after the Sinematek had begun collecting films that the Arsip Nasional followed suit. Important work done by the Arsip Nasional since 1980 has included organizing the repatriation of materials held in Dutch archives. It also has the responsibility for preserving surviving documentary film materials produced by Perusahaan Film Negara (PFN) or State Film Company, which had taken over production facilities from the departing Dutch, and from the early 1950s had been responsible for the making of government-produced documentary films and even some feature films. ${ }^{3}$ In the 1980 s, PFN produced the children's puppet series $\mathrm{Si}$ Unyil for state-owned television, and three government-funded big budget propaganda feature films, including the four-and-a-half hour Pengkhianatan G 30 S PKI [The Treachery of the Indonesian Communist Party in the 30th September Movement] (Arifin C. Noer, 1984).

Although Sinematek Indonesia had subsistence funding for operational costs, including the salaries of its employees, for the first thirty-five years of its existence it had no regular budget for restoration work or even for urgently required copying of material for the simple purpose of preservation. So, during those years Sinematek Indonesia has been largely a holding operation. If particular films were duplicated or subjected to some 
restoration process, it was usually a one-off negotiation with an outside organization. I first became conscious of this long lasting financial situation when in 1986 I requested a 35mm print of Sjuman Djaya's 1982 film Raden Ajeng Kartini (about the Javanese women's emancipist) for a screening at the Melbourne International Film Festival, and a newly subtitled print had to be made.

On occasions, if older Indonesian films held by the Sinematek were invited to major festivals, and subtitled prints suitable for overseas exhibition did not exist, the Dewan Film Nasional would request the making of new prints from negatives held at Sinematek Indonesia, but the cost incurred would be paid for by its umbrella organization, the Indonesian Department of Information. This practice occurred on a particularly large scale in the early 1990s, when the Dewan Film Nasional requested the making of blackand-white prints, with English subtitles, of numerous Indonesian film classics from the 1950s. These film classics-for most of which I provided subtitle translations, with assistance from a colleague at Monash University, Basoeki Koesasi-were shown, along with more recent Indonesian films, at a retrospective of Indonesian cinema curated by the Jakarta-based critic and film historian, Salim Said, and held in 1994 in New York by the New York Asia Society, and at Ohio State University and the University of Wisconsin.

In the 1980s and 1990s some copying projects were carried out with funding from other nations. The Japan Foundation funded the making of 16-millimeter prints of major films shot in cinemascope and in color by Teguh Karya, a leading director from the 1970s and 1980s (Karya, personal communication, January 1987). These prints had subtitles in both Japanese and English. In 1980 Biran funded the making of 16-millimeter prints of two important films by Sjuman Djaya, Si Mamad (1973) and Atheis [Atheist] (1974), because the negatives of these films, held at labs in Tokyo, were to be destroyed. Then, between 1981 and 1990, the Monash University Library, together with the National Library of Australia Film Studies Collection, funded the making of 16-millimeter dupe inter-negatives of these same two films from the single surviving 16-millimeter prints of each, preservation projects which I coordinated. The work was carried out by Colorfilm in Sydney, with the inter-negatives sent to Sinematek Indonesia in exchange for the right to make two 16-millimeter prints for use in Australia in an educational context. Subsequently, as a continuation of these preservation projects, a 16-millimeter dupe inter-negative and prints were made of a third film, Nji Ronggeng [The Ronggeng Dancer] (1969), from a single surviving 35-millimeter color print, funded by these same two organizations and with technical support from the National Film and Sound Archive of Australia (NFSA). In the late 1990s, the Pusan International Film Festival funded 
the making of an inter-negative and prints of the Indonesian film Antara Bumi dan Langit [Between Earth and Sky] (1950) (Hartono, personal communication, December 2001). This film had been directed by Hinatsu Eitaro, a Korean who was a former member of the Japanese occupation army propaganda unit and who had married an Indonesian and stayed on in Java, in the late 1940s advising the Republican government in Jogjakarta on the setting up of a film company and teaching film production courses there. Later, under the name of Dr Huyung, Hinatsu Eitaro directed three feature films in early independent Indonesia (Barker, 2017). He was also the director of the Japanese propaganda film Calling Australia that was made in Java in 1944 to show the "exemplary conditions" under which Australian prisoners of war were kept. The making of this film was the subject of Graham Shirley's Film Australia documentary Prisoners of Propaganda (1987).

\section{Research on Indonesian Film History by Sinematek Staff}

Despite the limited funding, Sinematek staff have been able to produce a substantial body of research on Indonesian film history, often also providing initial data on which works by others have been based. S.M. Ardan was heavily involved in the first joint publishing initiative of Sinematek Indonesia, the thick volume Apa Siapa Film Indonesia 1926-1979 [Who's Who in Indonesian Film] (1979), which includes biographical data and filmographies going back to the 1920s (Sinematek Indonesia dan Badan Penelitian Departemen Penerangan, 1979). Apa Siapa Film Indonesia was updated in 1999. Misbach Biran's lengthy Sejarah Film 1900-1950: Bikin Film di Jawa [Film History 1900 to 1950: Making Films in Java] is the primary source of knowledge of film in this early period of filmmaking in the Netherlands East Indies, particularly of the work of the Chinese producers and directors (Biran, 2009). An earlier, less complete version of this book appeared in 1994. In 1992, S.M. Ardan produced a book on film distribution in Indonesia, Dari Gambar Hidoep ke Sinepleks [From a Picture of Life to the Multiplexes], which discusses the relation between local production and competition from imports, outlining debates and changing policies about this important issue over many decades (Ardan, 1992). Sinematek's documentation section under Ardan would become an indispensable resource for the assembly of J. B. Kristanto's Katalog Film Indonesia, first published in 1994 but revised, expanded, and reissued twice, in 2005 and 2007. Its contents are now available on the Internet, regularly updated (Kristanto, 2005). ${ }^{4}$ This book provides synopses and lists of credits and other significant information, especially regarding awards or prizes for all known Indonesian films produced since 1926, extant or otherwise. Ardan himself wrote the entries for the period 1926-1969 (Kristanto, personal 
communication, August 14, 2017). Sinematek has also provided facilities and support for research done by both local scholars such as Salim Said and Tanete Pong Masak, and scholars from overseas, including Krishna Sen, Katinka van Heeren, Ben Murtagh, and myself (Said, 1982 \& 1991; Sen, 1994; van Heeren, 2012; Murtagh, 2013; Masak, 2016; Hanan, 2017).

\section{Industry and Policy Changes and their Impact on Sinematek Indonesia}

In the early 1990s, the Indonesian film industry-which in the 1970s and 1980s had produced an average of 70 feature films each year-experienced a rapid drop in production due to the introduction of commercial television in the late 1980s, and the preference for the screening of American films, particularly in the newly established Sinepleks Twenty-One chain of cinemas owned by businessman and film producer Sukwikatmono, a half-brother of President Suharto (Biran, 2001, 242-4). Economies of scale offered by import monopolies such as Sudwikatmono's meant that even smaller cinemas in regional areas had to screen large numbers of American films in order to survive. The number of films produced in Indonesia bottomed out in 1999, with only about five films produced locally in a country of well over 200 million people. Due to the contraction of the local industry in 1992, when only twenty-five films were produced, the annual Festival Film Indonesia was cancelled, and this situation continued until 2004. In 1992, the policy of having prints of films selected for competition in an annual film festival deposited in Sinematek at the behest of the Dewan Film Nasional (now defunct) lapsed. Nevertheless, examination of data lists shows that prints of quite a number of significant Indonesian films produced after 1992 were deposited in Sinematek.

In 1995 the governor of Jakarta decided to demolish the original building that housed the film center where Sinematek Indonesia was located. This building, completed in 1975, occupied a sizeable land area that included a large courtyard, and it was now to be replaced with a five-story building that occupied less space. For Sinematek this meant that in the basement of the new building they would have custom-designed cold-storage vaults for the first time. At the same time the governor proposed that income derived from renting out spare spaces in the new building to other organizations, including non-film related companies, would be a source of funding that would be administered by the $\mathrm{H}$. Usmar Ismail Film Centre Foundation (Yayasan Pusat Perfilman H. Usmar Ismail), a newly established organization that would be responsible for both Sinematek Indonesia and Yayasan Citra, a foundation specialising in training in film production (Jakarta's film archive in dire condition, 2012). Many film people, including Misbach 
Biran, questioned the appropriateness of an archive existing under this kind of non-government administrative framework (Biran, 2011).

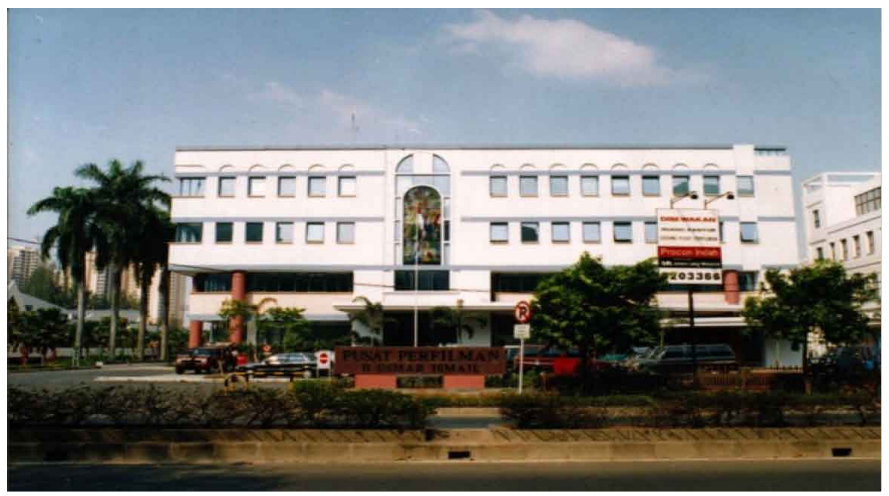

Fig. 3. The new Film Centre H. Usmar Ismail in Jalan Rasuna Said, Kuningan. It opened in 1997 and houses Sinematek Indonesia and other film organizations on the fourth and fifth floors, an air-conditioned cold storage vault in the basement, and an auditorium on the ground floor (Courtesy of Sinematek Indonesia).

Even more drastic in its consequences for Sinematek was the abolition of the Indonesian Information Ministry by President Abdurrahman Wahid in October 1999, some 18 months after the fall of Suharto (Barton, 2002, pp. 290-291). During the Suharto period, the Indonesian Department of Information, which had control not only of key aspects of film culture through bodies such as the Dewan Film Nasional and the Festival Film Indonesia, but of film censorship, had become a very large organization, with its tentacles reaching and controlling many aspects of Indonesian life, including the press and television. The particular policies regarding film, and interventions of the Indonesian Department of Information as custodian of the Film Censorship Board, have been explored in detail by Krishna Sen (Sen, 1994, pp. 66-71). It is believed that after some months in office, President Wahid decided it was not possible to reform the Indonesian Department of Information "due to its Stalinist approach to the control of information and because of its entrenched practice of extorting money from media outlets" (Barton, 2002, p. 290), and the only option was to abolish it entirely. While responsibility for film matters was now placed in the hands of the Ministry of Education and Culture and later would be shared with the new Board for a Creative Economy and Tourism, Sinematek was never made the responsibility of any ministry. Since 1998, it has not been a member of FIAF, for it could not afford to pay the membership fees.

The demise of the Ministry of Information also meant the demise of the Dewan Film Nasional and thus, too, the loss of funding for the operational costs of Sinematek that had been in place for twenty years. After the year 2000, funds for Sinematek's staff salaries and day-to-day operations have come solely from rental income of the building (Ardan, personal communication, December 2005). Since the early 2000s there has been no funding to replace departing staff, including the position of Deputy Director 
held by S. M. Ardan. Salaries are pegged at minimum wage for an unskilled worker in Jakarta-determined by the government-which all staff, except for the director, receive, irrespective of skills, job responsibilities, and length of service (Sandas, personal communication, June 2016). Funding of Sinematek is not sufficient to appoint people from a newly emerging generation who are professionally trained in archiving, especially those with overseas experience in this field. Realities like these tempt one to use the appellation "Third World Film Archive" for Sinematek Indonesia

\section{Size of the Collection and its Condition, According to Era}

The collection of films at Sinematek Indonesia is primarily important because it is a unique collection of feature films from various phases of Indonesia's feature film industry. However, the holdings vary considerably from era to era. Only about thirteen films from the pre-1950 period are held in the Sinematek collection, and most of these are not known to survive elsewhere. The earliest feature film material in the collection is a fragment from Tie Pat Kie Kawin [The Ghostly Pig Gets Married] (The Teng Chun, 1935). The scarcity of very early films in the collection would be due to the limited facilities for storing films adequately in humid tropical conditions and to the lack of care given films in these early years. At that time films tended to be regarded as valuable only in terms of their commercial life. Experts working in the field of film preservation in Indonesia, such as Orlow Seunke, director of the recently established Indonesian Film Center, which has been involved in film searches, are not confident that more film material from the colonial period up to 1949 will be found (Seunke, personal communication, July 20, 2017). However, the holdings of films from 1950 onwards are more substantial.

The following table displays the holdings at Sinematek according to period and film gauge. The figures I have collated are based on working lists of films in the collection, "Daftar Koleksi", held, along with the films, in the refrigerated basement vaults of the Sinematek. These lists are classified on the basis of film type, that is, whether they exist as a negative or a print, and whether they are in color or in black and white. Please note that all figures are provisional until an independent audit of the collection is carried out and the various lists of holdings are fully reconciled not only with each other but with the films held in the air-conditioned vaults.

\begin{tabular}{|l|}
\hline Black-and-white Prints \\
\hline 1935-1949 B \& W films on 35mm: 8 (mostly fragments) \\
\hline 1935-1949 B \& W films on $16 \mathrm{~mm}: 5$ (all listed as incomplete; one just fragments) \\
\hline 1950-1969 B \& W films on 35mm: 46 \\
\hline
\end{tabular}




\begin{tabular}{|l|}
\hline 1950-1969 B \& W negatives without prints: 48 \\
\hline 1950-1969 B \& W films on 16mm: 12 (all incomplete and in poor condition) \\
\hline Black-and-white Negatives \\
\hline 84 (almost all of these films were produced between 1950 and 1968) \\
\hline Color Prints produced since 1969 \\
\hline Color films on 35mm: 303 films \\
\hline Color films on 16mm: 58 (45 of these titles are held also as $35 \mathrm{~mm}$ prints or negs) \\
\hline Color Negatives returned from overseas laboratories \\
\hline $\begin{array}{l}\text { Total estimated 35mm color negatives: } 399 \text { approx. } \\
\text { Total 16mm dupe inter-negatives of films originally produced on 35mm: } 3 \text { films }\end{array}$ \\
\hline
\end{tabular}

Table 1: Celluloid Prints and Negatives of Feature Films in the Sinematek Indonesia Collection

Based on my calculations, if these listings are correct, the total number of film titles for which some preservation material is held would be about 825 films. However, the condition of many of the prints and negatives in the collection and the methods available for keeping them in good condition give serious cause for alarm. An article entitled "Notes from Sinematek Indonesia's Film Storage: Only 14\% and They Are Decaying" published by Kartikasari (2012a; 2012b), a graduate of the Jakarta Institute of the Arts Faculty of Film and Television, reports that the normal archive practice of regularly cleaning films to keep them in good condition is severely compromised at Sinematek due to the small amount of funding that limits particularly the purchase of necessary cleaning chemicals. Kartikasari provides technical explanations as to the resulting deterioration and includes a three-page list, supplied to her by Sinematek, of 100 films in critical condition, with annotations as to the extent of the damage. This list includes both films from the colonial period and much more recent color films. One wonders if the overseeing body for Sinematek, YPPHUI, recognizes the seriousness of this situation, and might exert more effort to find the funds to address the problem.

Below I have compiled the survival rates (in percentage) in relation to the total films made for a particular period. Some of the surviving materials are not necessarily complete films in good condition. My figures differ from those of Kartikasari (2012a; 2012b) because she does not include the 402 negatives returned from overseas labs that have been stored at Sinematek. It is true, though, that whatever the overall survival rate, only 10 percent of the original celluloid collection is accessible (Rahman, 2012). The following figures show that this is an exceptional collection, but under threat. ${ }^{5}$ 


\begin{tabular}{|l|c|c|l|}
\hline \multicolumn{4}{|c|}{ SURVIVAL RATES OF FILMS (EITHER AS PRINTS OR NEGATIVES) } \\
\hline \multicolumn{1}{|c|}{ Years } & $\begin{array}{c}\text { Films } \\
\text { Produced }\end{array}$ & $\begin{array}{c}\text { Films in } \\
\text { Sinematek }\end{array}$ & \multicolumn{1}{c|}{ Survival Rate } \\
\hline $\begin{array}{l}\text { Colonial Period } \\
1926-1949\end{array}$ & 116 & 13 & $\begin{array}{l}11.2 \% \text { of titles, mainly } \\
\text { fragments }\end{array}$ \\
\hline $\begin{array}{l}\text { Early Independence Era. Films were } \\
\text { made in Black \& White only. } \\
1950-1969\end{array}$ & 545 & 106 & $\begin{array}{l}19.4 \% \text { with those on } \\
16 \text { mm with major } \\
\text { damage }\end{array}$ \\
\hline $\begin{array}{l}\text { Films made in Color } \\
1969-\text { Aug 2017 }\end{array}$ & 2864 & 696 approx. & $\begin{array}{l}24.3 \% \text { in varying } \\
\text { conditions }\end{array}$ \\
\hline TOTAL & 3525 & 815 approx. & $23.1 \%$ \\
\hline
\end{tabular}

Table 2. Survival rate of fiction films produced in different periods of film production in the Indonesian archipelago, based on films held by Sinematek Indonesia.

\section{Some Observations on the Sinematek Collection}

Under policies established by the second Head of Sinematek Indonesia, Adi Pranadjaya (period of office 2001-2009), access to the feature film collection is now provided through video viewing facilities using mainly DVD copies of most of its print holdings. According to Sinematek staff managing the viewing room, the DVD copies have usually been made not by any telecine process but by videotaping the films as they are being screened in a preview theater. The viewing collection is further augmented with commercially produced video tapes and VCD and DVD disks, together with disks of older Indonesian films recorded from television. For a fee, some 35-millimeter prints, particularly those for which a negative in good condition is still extant, can be viewed on a Shinko editing table in the basement vaults.

In 2010 the third appointed Head of Sinematek, H. Berthy Ibrahim Lindia, who claimed to have based his policies fully on film archiving guidelines established by FIAF, decided that henceforth single prints of films cannot be sent abroad to film festivals, unless it could be clearly determined that other surviving copies of the films or a negative have been safely preserved (B. Lindia, personal communication, November 2011). The access point for the DVD collection at Sinematek is also the point of access to its substantial collection of photos and stills, available for viewing in digitized form. Access to most early state-produced Indonesian documentaries is via the National Library of Indonesia, based on its connection to the Indonesian National Archives.

Below are my comments regarding some key films held at Sinematek Indonesia that I have been able to access. 
(1) The earliest surviving fragment in the collection, Tie Pat Kie Kawin [The Ghostly Pig Gets Married] (1935), directed by pioneering Chinese-Indonesian producer-director, The Teng Chun, was only recently rediscovered. It was quickly digitized with a special grant from the Ministry of Education and Culture. In 2014, there was still one film on nitrate held in the vaults: Matjan Berbisik [Whispers of the Tiger] (1940). It was scanned by staff at the new Indonesian Film Centre in 2015.

(2) The largest single set of films by one group, held in the Sinematek, is the collection of films by the Perfini Company. Perfini was founded in 1950 by the writer-director Usmar Ismail, whose company produced films directed by himself and his protégés, mainly Djayakusuma and Nya Abbas Akup, particularly in the 1950s. At least fifteen of these Perfini films survive as prints and negatives, including the three epic films that Usmar Ismail directed in the early 1950s about the period of struggle for independence: Darah dan Do'a [aka The Long March] (1950), Enam Djam di Djogdja [Six Hours in Jogja] (1951), and Lewat Djam Malam [After the Curfew] (1954). ${ }^{6}$ These films are interestingly compared with Italian neorealist works. They are nationalist epics celebrating the birth of the nation at a time of armed conflict, made using a neorealist mode of production, and two of them question aspects of how the nation came into being. For example, Lewat Djam Malam deliberately depicts human rights abuses by nationalists, including freedom fighters killing unarmed civilian refugees for reasons of personal gain. Undoubtedly these fifteen or so Perfini films have survived because Usmar Ismail was a producer as well as a writer-director, with his own production house, where films directed by himself and his protégés were stored, well into the 1970s, and later. The Perfini collection also includes other innovative Perfini films directed by Usmar Ismail, such as Tiga Dara [Three Maidens] (1955) and Asrama Dara [Girls' BoardingHouse] (1956), where Ismail attempted to develop a commercial popular cinema suitable for Indonesia, by emulating the Hollywood musical. It also includes significant works made in regional areas by his colleagues, notably Harimau Tjampa [The Tiger from Tjampa] (Djayakusuma, 1953), filmed in the highlands of West Sumatra among the matrilineal Minangkabau people.

(3) The most celebrated recent restoration project has been the restoration completed in 2012 of Usmar Ismail's Lewat Djam Malam (1954) by L'Immagine Ritrovata, the film restoration laboratory at the Cineteca Di Bologna. ${ }^{7}$ At the suggestion of Philip 
Cheah, former programmer for the Singapore Film Festival, a digital restoration of an Indonesian film was to be funded by the National Museum of Singapore, as one of a set of film restoration projects with neighbouring Southeast Asian countries, in an attempt to stimulate more support for film restoration in the region (Rahman, 2013). It was J. B. Kristanto, editor of the Katalog Film Indonesia, who nominated Lewat Djam Malam as a significant film most in need of restoration (Cheah, personal communication, October 15, 2011). As Cheah reports, Kristanto was aware of the parlous state of the surviving 35-millimeter materials of this film, with scenes out of order, sound mismatched, and imagery marred at points through faults in the printing. The restored version was screened at the Cannes Film Festival in May 2012 as part of Martin Scorsese's World Cinema Foundation program. It was subsequently premiered in Indonesia by the Sinematek, and then shown at a commercial cinema in Jakarta. In 2015, Ismail's Tiga Dara (1955) was also restored by L'Immagine Ritrovata.

(4) The question has been raised, mainly in seminars and private conversations, as to whether the collection at Sinematek Indonesia has been influenced by political attitudes. Some have suggested that Sinematek, established late in the first decade of the Suharto years, excluded the preservation of works by left-wing directors. Misbach Biran, a strict Muslim strongly opposed to atheistic communism, has always claimed that he collected films irrespective of the religious or political beliefs and reputation of filmmakers (Biran, personal communication, 1989). This is largely borne out by an examination of the collection. There are at least five films held in Sinematek directed by the left-wing directors Kotot Sukardi and Basuki Effendi, and one by Bachtiar Siagian. At least three of these films, Si Pintjang [The Lame] (Kotot Sukardi, 1952), a film set among the poor, Djajaprana (Kotot Sukardi, 1953), based on a Balinese legend, and Si Melati (Basuki Effendi, 1954) were made for the State Film Company (PFN). Effendi and Siagian were among the artists imprisoned for nearly twelve years after the nationwide purge of the left in Indonesia in 1965-1966 (Sen, 1994, p. 49). To my knowledge, Sinematek had collected these directors' films by 1983 at the latest, at a time when any association with communist ideas could still be dangerous for a citizen of Indonesia. A sixth film, Violetta (Bachtiar Siagian, 1961), the only known surviving film by Siagian, was acquired by Sinematek from a collector in 1993. Sukardi, Effendi, and Siagian altogether made a total of about 
thirty films, and about 20 percent of their films have survived, which is the statistical average survival rate for Indonesian films made in the 1950s. ${ }^{8}$ Nevertheless, Sinematek Indonesia did not hold any screenplays of films by Siagian, and these were obtained by Australian-based researcher Krishna Sen, who interviewed Siagian in the early 1980s, having sought him out in Jakarta after his return from imprisonment on Buru Island in the Moluccas where he was imprisoned with other distinguished artists, including the novelist Pramoedya Ananta Toer (Sen, personal communication, 1982). Copies of the screenplays obtained by Sen were placed in the Sinematek Indonesia library, where they can still be obtained today. Sen has written at some length about the films of Bachtiar Siagian (Sen, 1994, 41-6).

(5) The names of left-wing artists are sometimes removed from the credits of films. Credits for Usmar Ismail's satire on Sukarno's presidential style, Tamu Agung [Exalted Guest] (1955), have the name of coscriptwriter Basoeki Resobowo removed. Resobowo was overseas at the time of Suharto's hunt for communists, a hunt that included as targets artists associated with the left-wing arts organization LEKRA. Resobowo remained in exile in Holland until his death. It is not clear whether his name was removed by Sinematek Indonesia or, as is more likely, by the staff of the Perfini company in late 1965 in order to protect the film. However, Resobowo's name is listed in the Katalog Film Indonesia as one of the writers for Tamu Agung.

(6) Sinematek Indonesia does hold some films that require specialized restoration work. One example is Matt Dower (Nya Abbas Akup, 1969), a brilliant and subversive political allegory on the then recent power struggle between General Suharto and President Sukarno, which resulted in the removal of Sukarno from office (Hanan, 2009, pp. 23-8). Funded-strange as it may seem-by the Indonesian Ministry of Information, and filmed in color, Matt Dower, on its completion greatly alarmed officials when they came to understand its satirical purpose. The film was therefore suppressed in the following way: its release was put on hold for six months or so, and then it was released only in black and white, at a time when color films were for the first time being made in Indonesia and few people wanted to see an Indonesian film in black and white (Nya Abbas Akup, personal communication, 1989). Its sole surviving black-andwhite release print, acquired by the Sinematek in the late 1980s, was a washed-out print based on the color negative, which had long been lost or, more likely, destroyed. To achieve a better approximation 
of the quality of this extraordinary film, any digitized version of the surviving print would need extensive further work to produce adequate black-and-white contrasts in the image.

(7) The Sinematek collection also contains a collection of documentary films, mainly on 16-millimeter gauge. A substantial number of these are from the private collection of the Jakarta publisher, Mas Agung, who donated his private collection of Indonesian documentary films and newsreels, including some editions of the newsreel Gelora from 1945 onwards, particularly from the 1950s and 1960s. Many documentaries about Indonesia by foreign filmmakers are held by Sinematek as well as in other archives. The Sinematek holds a copy of Joris Ivens' Indonesia Calling, filmed in Sydney in 1946, donated by Australia. Depositing a copy of a foreign-made film about Indonesia in an Indonesian archive eventually became a requirement of the Indonesian Department of Information. There are also films donated by various embassies, including a collection of 270 films made by the National Film Board of Canada.

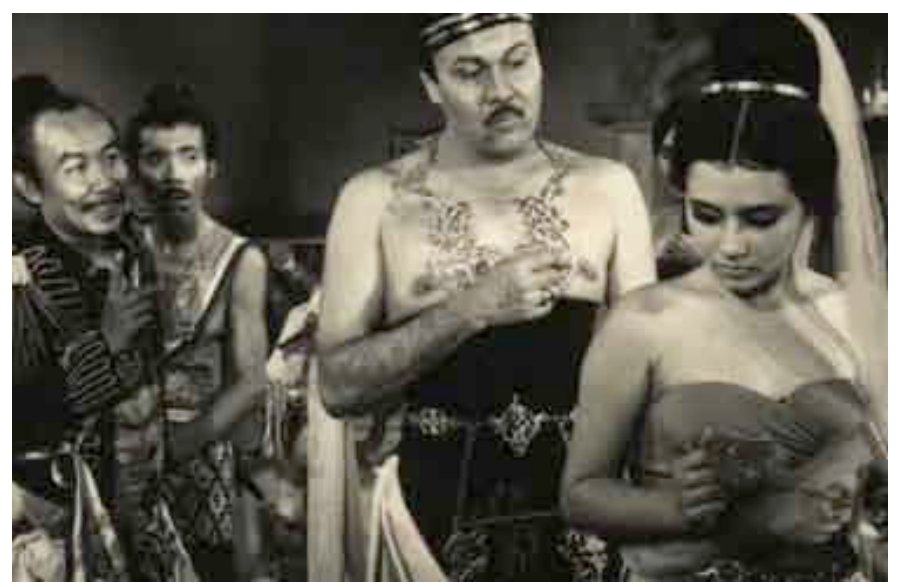

Fig. 4. Production still from Matt Dower, showing the new leader, addressed respectfully as 'Munafik' (Hypocrite) (left), cautioning other stakeholders in the court (Courtesy of Sinematek Indonesia).

Sinematek Indonesia also has a well-organized library containing approximately 2000 screenplays of Indonesian films; 282,798 clippings from newspapers and magazines, initially based on Biran's research in Jakarta and Amsterdam in the early 1970s, together with clippings systematically collected on a daily basis by staff since 1975; and books. The exceptionally large number of screenplays in the collection is due not only to assiduous work on the part of the staff but also to the fact that during the Suharto New Order period, from 1968 to about 20 years after, the Department of Information required that a copy of a screenplay for each film seeking production approval be deposited with the department (Hanan, 2017, 
p. 72). This requirement was initially part of a scheme for allocating government funding for the very few quality projects of the short-lived National Film Production Council, that was established in 1968. With the demise of the council, which had funded Matt Dower and three other films, this requirement became a means by which the Indonesian Department of Information could engage in the pre-censorship of films.

However, the Sinematek library also faces numerous problems. Given the funding arrangements in place since the demise of the Dewan Film Nasional, Sinematek has a monthly operating budget for stationery and related library requirements that barely meets essential needs. It has, at most, Rp200,000 (US\$15) per month, to purchase newspapers containing reviews of films, which it then documents (Sinematek library staff, personal communication, July 2017). Books, periodicals, and even magazines have mainly been acquired by the library through donations. The library is located on the top floor of the building, and its roof leaks onto the collection. Computers have been supplied through a co-operative arrangement with the National Library, because Sinematek has no money to purchase computers for its own library, but recently during a heavy downpour, new leaks occurred in the roof and this impacted one of the computers and a printer. Fumigation is expensive, costing about US\$2000 every time. But although necessary, there is no money for fumigation. In 2013 the head of the library resigned out of frustration with working conditions in the library (Cenik, personal communication, 2014).

\section{A Film Archive in a Coma?: New Developments and Challenges}

In a document he wrote less than one year before his death, Biran summarized the various stages Sinematek has gone through since its inception. The document culminated with Sinematek being described in its current situation as akin to "a man in a coma" (Biran, 2011, p. 5). Biran protested that due to lack of funding there had been no substantial growth in the Sinematek in the previous ten years, neither with regard to the collection nor to its activities. He expressed alarm for the lack of funds for the maintenance of storage vaults and their cooling and air conditioning equipment. He lamented the woefully inappropriate salaries provided to his staff. He complained about Sinematek's relations with YPPHUI, noting that communication between Sinematek and the foundation is itself very poor, for the latter does not seem to understand the purpose of Sinematek nor comprehend that libraries and archives have to be based on idealism. Even the ability of Sinematek to use its unique collection to educate people about Indonesian film-a key priority of Biran in earlier times-has diminished. In November 2012, Pak Berthy Lindia was replaced as head of Sinematek 
by the foundation charged by the Jakarta City Council with overseeing Sinematek Indonesia, Yayasan H. Usmar Ismail Film Centre (YPPHUI). The reason behind the move was not made clear, but some say that quite possibly Pak Berthy had different priorities from those of the YPPHUI head (Kepala Sinematek dinonaktifkan, 2013). ${ }^{9}$ Here it is worth noting that the late Misbach Yusa Biran had held the view for quite some time before his death that Sinematek did not need to be "supervised" by an intermediary body such as the YPPHUI and should be funded by and be answerable directly to a government department, though independent of it.

In 2013, a new Sinematek head was appointed: Adi Surya Abdi, a producer-director active in the film industry since the 1980s. It is my understanding that Pak Adi has worked amicably with both YPPHUI and with Orlow Seunke of the Indonesian Film Centre, whose entrepreneurial activities and technical knowledge are of great benefit to Sinematek. The work of the Indonesian Film Centre in digitizing irreplaceable films in the Sinematek Collection has enabled Sinematek to move forward in matters concerning the preservation of its collection via digitization.

In 2011, H. Berthy Ibrahim Lindia, then still head of Sinematek Indonesia, had conducted negotiations with the Indonesian Ministry for Education and Culture to obtain funding for the digitization of the collection to commence (B. Lindia, personal communication, November 3 , 2011). This ministry supplied a total of about US $\$ 300,000$ to commence digitization, and twenty-nine titles were digitized, most of the work carried out by the technologically proficient Jakarta-based company Render Post Studio. According to Pak Berthy, some further films held by Sinematek, that were of continuing commercial value based on TV sales, such as comedies and musicals by the singers Benyamin S and Rhoma Irama, were digitized in Chennai, India, the costs covered by their rights holders. Pak Berthy also expressed hope that some highly regarded films, such as Sjuman Djaya's Atheis (1975), would be prioritized for full restoration as soon as possible.

Dutch film director Orlow Seunke, who has been a resident of Indonesia for some time now, has set up an "Indonesian Film Center" on the fifth floor of the same building as Sinematek Indonesia. Since 2014 Orlow has initiated further digitization of important films made in Indonesia, with films held by Sinematek as a priority. His staff have been using a D-Archiver $2 \mathrm{~K}$ scanner to carry out the digitization. Since prints held by Sinematek are mainly viewing prints screened at film festivals, and not preservation prints, the center contacts producers, when necessary, to obtain better quality source materials to scan (K. Muchtar, personal communication, August 11, 2017). The Indonesian Film Centre has a comprehensive website outlining its activities: http://www.indonesianfilmcenter.com/. Between February 2015 
and mid-2017, about 200 films from Sinematek Indonesia were scanned. The Indonesian Film Center is hoping to scan on average at least 100 films a year and is seeking to obtain funding for a second scanner. It estimates that it will take up to seven years to complete the scanning of films at Sinematek alone. They are also scanning films from other sources. Substantial funding for this preservation project has been provided by the Ford Foundation in Jakarta and by the businessman Hashim Djojohadikusumo, a brother of former army general Prabowo Subianto, one-time son-in-law of the late President Suharto.

According to latest reports (June 2018), the Indonesian Film Center has moved its office from the Pusat Perfilman H. Usmar Ismail building in Kuningan, where the Sinematek is located, to premises in the Kampung Melayu area in East Jakarta, owing to the increased costs of renting its spaces on the fifth floor of the building at Kuningan from the Yayasan Pusat Perfilman H. Usmar Ismail.

Clearly Sinematek and its supporters are doing a lot on a very limited budget. While urgent preservation issues are now being addressed by the Indonesian Film Centre via its digitization project, it is truly to be hoped that at the Sinematek Pak Adi Surya Abdi can develop new funding and administrative frameworks by which the following important issues can be addressed: appropriate day-to-day operational funding; fair salaries for staff, with enhanced salaries for those professionally trained; idealistic and informed management at all levels, with a clear understanding of international recommendations on film archiving of celluloid materials and the particular problems Sinematek is facing in preserving its celluloid collection; proper budget for infrastructure and equipment, including computers and photographic equipment for staff to carry out their numerous tasks, whether in the stills collection or in the library; and funding earmarked for urgent preservation needs and priority restoration projects. Inevitably this requires more direct government funding, with the archive ultimately overseen by and responsible to a Ministry that provides more adequate funding for the important national heritage tasks it is carrying out. Can Sinematek Indonesia survive and grow if it must continue to rely only on the good will of idealistic helpers and intermittent benefactors? 


\section{References}

Ardan, S. M. (1992). Dari gambar idoep ke sinepleks [From a picture of life to the multiplexes]. Jakarta: GPBSI.

Ardan, S. M., Saputra, Y. A., \& Sjafi'ie, I. (2000). Siklus Betawi: Upacara dan adat-istiadat [The Betawi cycle: Ceremonies and customs]. Jakarta: Lembaga Kebudayaan Betawi LKB bekerjasama dengan Dinas Kebudayaan Propinsi DKI Jakarta.

Barker, T. (2017). Colonial mobility and ambiguity: The life of filmmaker Hinatsu/Huyung. TRaNS: TransRegional and -National Studies of Southeast Asia 5 (2), 197-215.

Barton, G. (2002). Gus Dur: The authorized biography of Abdurrahman Wahid. Jakarta: Equinox Publishing. Biran, M. Y. (1998). Ikhtisar sejarah Sinematek Indonesia [A survey of the history of Sinematek Indonesia] (Unpublished paper). Jakarta:H. Misbach Biran Papers, Library of Sinematek Indonesia.

Biran, M. Y. (2001). The history of Indonesian cinema at a glance. In D. Hanan (Ed.), Film in South East Asia: Views from the region. Hanoi: SEAPAVAA and Vietnam Film Institute.

Biran, M.Y. (2008). Kenang-Kenangan orang bandel [Reminiscences of a stubborn man].Jakarta:Komunitas Bambu.

Biran, M.Y. (2009). Sejarah film 1900-1950: Bikin film di Jawa [Film history 1900-1950: Making films in Java]. Jakarta: Komunitas Bambu dan Dewan Kesenian Jakarta.

Biran, M.Y.(2011).Ikhtisar sejarah Sinematek Indonesia \& Pusat Perfilman H.Usmar Ismail [A recapitulation of the history of Sinematek Indonesia \& the Film Centre H. Usmar Ismail] (Unpublished paper). H. Misbach Biran Papers, Library of Sinematek Indonesia.

Hanan, D. (2009). A tradition of political allegory and political satire in the Indonesian cinema. In Y. Michalik and L. Coppens (Eds.), Asian hot shots: Indonesian cinema (pp. 14-45). Marbug: Schuren Verlag $\mathrm{GmbH}$.

Hanan, D. (2017). Cultural specificity in Indonesian film: Diversity in unity. London: Palgrave Macmillan.

van Heeren, K. (2012). Contemporary Indonesian cinema: Spirits of reform and ghosts from the past. Leiden: KITLV Press.

Jakarta's film archive in dire condition (2012). Jakarta Post (21 May). Retrieved from http://www. webcitation.org/68YcvFJbj.

Kartikasari, A. (2012a). Catatan dari ruang penyimpanan film Sinematek Indonesia. Hanya 14 persen yang tersimpan dan dalam kondisi memprihatinkan. In A. J. Pasaribu \& J. B. Kristanto (Eds.), "Lewat Djam Malam"diselamatkan (pp.93-102). Jakarta:Sahabat Sinematek. Retrieved from http://filmindonesia. or.id/article/lewat-djam-malam-diselamatkan-unduh-buku-dan-video\#.WZFITyN94UE.

Kartikasari, A. (2012b). Notes from Sinematek Indonesia's film storage: Only 14\% and They Are Decaying. In A. J. Pasaribu \& J. B. Kristanto (Eds.), "Lewat Djam Malam" restored (pp. 93-102). Jakarta: Sahabat Sinematek. This article was originally published in the Indonesian language in the same year, in Pasaribu and Kristanto's "Lewat Djam Malam" diselamatkan (Jakarta: Sahabat Sinematek).

Kepala Sinematek dinonaktifkan [Head of Sinematek declared non-active]. (January 2013). Kabar Film, Edisi 41.

Kristanto, J. B. (Ed.). (2005). Katalog Film Indonesia (2nd ed.). Jakarta: Nalar, Bekerjasama dengan Fakultas Film dan Televisi, Institut Kesenian Jakarta, dan Sinematek Indonesia. 
Lombard, D. (1973). Images des cinémas Indonésien et Malaysien. Archipel 5(1), 103-34 (Special edition on film in Indonesia and Malaysia). Retrieved from http://www.persee.fr/doc/arch_0044-8613_1973_ num_5_1_1044.

Masak, T. P. (2016). Sinema pada masa Soekarno [Cinema in the Soekarno era]. Jakarta: Fakultas Film dan Televisi, Institut Kesenian Jakarta.

Minarchek, M. (2015). The National Archives of the Republic of Indonesia (ANRI). Retrieved from http:// dissertationreviews.org/archives/12299.

Murtagh, B. (2013). Genders and sexualities in Indonesian cinema: Constructing gay, lesbi and waria identities on screen. London: Routledge.

National Archives of the Republic of Indonesia (2014).Guide: Asian-African Conference archives - Chapter 2.8: Inventory of Produksi Film Negara (PFN) archives. Retrieved from https://goo.gl/Wd4yyt.

Pane, A. (1953, Jan-Feb). Produksi film tjerita Indonesia: Perkembangan sebagai alat masyarakat [The production of story films in Indonesia: Its growth as an instrument of the people]. Indonesia: Madjalah Kebudayaan 1(2), 5-112.

Rahman, L. (2012). Are we only worthy of watching broken films? Sinematek Indonesia and the future generation of Indonesia. In A. J. Pasaribu \& J. B. Kristanto (Eds.), Lewat Djam Malam Restored (pp. 93102). Jakarta: Sahabat Sinematek.

Rahman, L. (2013). Archiving outside of the frame, the story continues: Case study of Lewat Djam Malam film restoration project (MA dissertation). University of Amsterdam, Graduate School of Humanities. Retrieved from

http://scriptiesonline.uba.uva.nl/document/489519.

Ramadhan, K. H., \& Biran, M. J. (1973). Les vedettes du cinéma Indonésien [Stars of the Indonesian cinema] trans. P. Labrousse. Archipel 5(1), 165-74 (Special edition on film in Indonesia and Malaysia). Retrieved from http://www.persee.fr/doc/arch_0044-8613_1973_num_5_1_1048.

Said, S. (1982). Profil dunia film Indonesia [A profile of the Indonesian film world]. Jakarta: Grafitipers.

Said, S. (1991). Shadows on the silver screen: A social history of Indonesian film. Jakarta:The Lontar Press.

Sen, K. (1994). Indonesian cinema: Framing the New Order. London: Zed Press.

Setijadi-Dunn, C., \& Barker, T. (2010). Imagining "Indonesia": Ethnic Chinese film producers in preindependence cinema. Asian Cinema 21(2), 25-47.

Sinematek Indonesia dan Badan Penelitian Departemen Penerangan. (1979). Apa siapa orang film Indonesia 1926-79 [Who's who in Indonesian film 1926-1979]. Jakarta: Yayasan Artis Film dan Sinematek Indonesia. 


\section{Notes}

1 In addition to using documents, books, articles, and websites referred to in these endnotes, this essay is based on knowledge gained from my frequent research at Sinematek Indonesia over a thirty five year period, where at different times I have had lengthy discussions with its founding head, H. Misbach Yusa Biran, its deputy head for nearly thirty years, S. M. Ardan, and the recent heads, Adi Pranadjaya, $\mathrm{H}$. Berthy Ibrahim Lindia and Adi Surya Abdi, all of whom were readily available for conversation. Additionally, I wish to thank those staff who have worked (or are currently working) in the various sections of Sinematek, for their help, information, and advice. In particular I wish to thank Nia, the former librarian; Hartono, at one time in charge of prints and negatives in the vaults and now working for the Indonesian Film Centre; Sandas in photos and audio-visual access; and Firdaus, currently in prints and negatives. Thanks are due also to Orlow Seunke and Kiki Muchtar of the newly established Indonesian Film Centre, and to Lisabona Rahman and J. B. Kristanto.

2 In May 1980 Sadikin became known as a critic of the Suharto New Order regime, as a leading member of the oppositional circle, known as "the Petition of 50", and as a signatory to their petition, which criticised Suharto's use of the national philosophy, the Pancasila (The Five Principles). It has never been claimed, however, that this development impacted on Sinematek Indonesia.

3 Some of these documentary films did not survive in Indonesia. One early film made by PFN was a 67-minute documentary, Pandit Nehru Visits Indonesia, on the visit of Indian Prime Minister Nehru to Indonesia in June 1950, only six months after the Indonesians achieved independence. Nehru, along with Australian Prime Minister, Ben Chifley, had been one of the first international leaders to support Indonesian independence. In July 1947 both made urgent appeals to the Security Council of the newly established United Nations, protesting the recently commenced Dutch military action against Republican-held areas in Java. A copy of Pandit Nehru Visits Indonesia is held at the National Film and Sound Archive of Australia.

4 The contents of Kristanto's catalogue, regularly updated, are available as a web resource, and can be retrieved from http://filmindonesia.or.id/movie.

5 Figures for numbers of films produced in Indonesia in different periods have been retrieved from filmindonesia.or.id. Please note that figures in this online database keep changing even for earlier periods. For example: the recent inclusion of two fiction films with documentary elements produced by missionaries in Flores in 1930 and 1932, Ria Rago and Amorira (J. B. Kristanto, personal communication, August 14, 2017).

6 Some foreign-based scholars (Setijadi and Barker, 2011) have argued that the discourse of "film nasional" associated with films by Usmar Ismail tends to marginalize the role of the Chinese in pioneering an Indonesian film industry in the period 1927-1949.

7 Information about'L'Immaginate Ritrovata'film restoration laboratory in Bologna, can be retrieved from the following two websites:http://www.immagineritrovata.it/ and http://www.hollywoodreporter. com/news/film-restoration-labs-thrive-expanding-579752.

8 It has never been established exactly what happened to the twelve lost films that Bachtiar Siagian made for a variety of companies. Were some discarded after their commercial life ended, or 
when companies closed? Or were negatives and prints destroyed by the authorities, or out of fear by producers, or in fires lit by rioting crowds after the political crisis of 1965 ?

9 According to the press report in Kabar Film, Pak Berthy Lindia was declared "dinonaktifkan" or "non-active" as Head of the Sinematek, by the Yayasan, on the grounds that he had failed to sufficiently communicate with them regarding forthcoming digitization projects, and particularly the highly publicized recent restoration of Lewat Djam Malam.

After completing an MA in Comparative Literature at the University of Melbourne, and a Postgraduate Diploma in Film Studies at the Slade School of Fine Art at University College London, DAVID HANAN pioneered the Film Studies program at Monash University in Melbourne, Australia, from 1978. He has researched Indonesian film at Sinematek Indonesia since 1983, and has published widely on Indonesian film. He has been involved in film preservation projects working jointly with Sinematek Indonesia; has done translations for subtitles of about 15 Indonesian films; and for more than a decade distributed Indonesian films on DVD from a website at Monash University. His book Cultural Specificity in Indonesian Film: Diversity in Unity has recently been released by Palgrave Macmillan. (corresponding author: David. Hanan@unimelb.edu.au). 